\title{
Peningkatan Pengetahuan dan Keterampilan Pengolahan Limbah Ikan Kepada Kelompok Nelayan Tradisional Secara Daring di Belawan, Sumatera Utara
}

\author{
Naufal Huwaidi ${ }^{1}$, Ellen Lumisar Panggabean ${ }^{2}$, Indah Apriliya ${ }^{3}$ \\ ${ }^{1,2}$ Universitas Medan Area, Jalan Kolam Nomor 1 Medan Estate/Jalan Gedung PBSI, Medan \\ 20223 \\ Email: Indahapriliya93@gmail.com³
}

\begin{abstract}
ABSTRAK
Pengelolaan limbah ikan dari pengolahan ikan asin atau tawar saat ini hanya di buang dan di timbun begitu saja sehingga menimbulkan bau kurang enak dan dapat mengganggu kesehatan masyarakat sekitar. Program ini bertujuan untuk meningkatkan pengetahuan dan keterampilan pengolahan limbah ikan menjadi pakan ternak yang memiliki nilai ekonomis sehingga berpotensi menjadi suatu unit usaha baru bagi masyarakat. Kegiatan ini terdiri atas 4 tahap yang meliputi persiapan, pelatihan online 1 dan 2, serta evaluasi program. Kegiatan pelatihan dilaksanakan secara daring menggunakan aplikasi Zoom Meeting Online. Pelaksanaan program ini sangat bermanfaat bagi mitra sasaran dan telah meningkatkan pengetahuan masyarakat mitra dalam mengolah limbah ikan yang setiap hari dihasilkan menjadi suatu pakan ternak. Pengolahan limbah ikan menjadi pakan ternak dapat menjadi alternatif unit usaha baru yang dapat meningkatkan penghasilan terutama bagi pemuda yang terkena PHK akibat pandemi dan bagi ibu rumah tangga yang ingin mendapatkan pemasukkan tambahan.
\end{abstract}

Kata kunci: Belawan, Limbah Ikan, Pelet, Pakan Ternak

\begin{abstract}
Management of fish waste from salted or fresh fish processing is currently only being thrown away and piled up, causing a bad smell and can disturb the health of the surrounding community. This program aims to improve knowledge and skills in processing fish waste into the animal feed which has economic value so that it has the potential to become a new business unit for the community. This activity consists of 4 steps including preparation, online training 1 and 2, and program evaluation. All of the activities are carried out online using the Zoom Meeting Online application. This program is very useful for the community and has increased the knowledge in processing fish waste into animal feed. It could be an alternative to new business units that can increase income, especially for youth who have been laid off due to the pandemic and for housewives who want to get additional income.
\end{abstract}

Keywords: Belawan, Fish waste, Pellet, Animal feed

\section{PENDAHULUAN}

Pelabuhan Perikanan Samudera Belawan (PPS) merupakan salah satu pelabuhan perikanan terbesar di Sumatera Utara. PPS Belawan mempunyai peran penting dalam kegiatan perikanan tangkap dan pemasarannya. PPS Belawan terletak pada posisi yang 
cukup strategis, yakni terletak diantara Perairan Pantai Timur Sumatera (Selat Malaka), Perairan Zona Ekonomi Ekslusif Indonesia (ZEEI) dan Laut Cina Selatan, serta merupakan pintu masuk bagi kegiatan ekonomi beberapa negara di Asia (Siahaan dkk., 2016).

Berdasarkan hasil survei yang dilakukan tim Program Kreativitas Mahasiswa Bidang Pengabdian Kepada Masyarakat Universitas Medan Area (PKM M UMA), diperoleh data bahwa kelompok nelayan di lingkungan 6 Belawan dapat mengolah ikan menjadi ikan asin atau tawar mencapai \pm 1 ton/hari. Ada beberapa jenis ikan yang sering mereka olah menjadi ikan asin atau tawar seperti: Ikan kepala batu, ikan ledang, ikan pisang, ikan senangin dan ikan tenggiri. Ikan yang dapat diolah menjadi ikan asin atau tawar hanyalah bagian badannya saja, kepala dan isi perutnya akan di buang karena tidak dapat diolah. Potensi ikan yang dapat diolah oleh kelompok nelayan hanyalah $70 \%$ dari keseluruhan dan 30\% sisanya merupakan limbah dari pengolahan ikan asin atau tawar. Banyaknya limbah dari pengolahan ikan yang mencapai $\pm 300 \mathrm{Kg}$ perhari akan menimbulkan permasalahan berupa pencemaran lingkungan.

Rendahnya pendapatan kelompok nelayan dan banyaknya jumlah pemuda pengangguran akibat wabah COVID-19 ini mengakibatkan melemahnya perekonomian masyarakat pesisir. Mayoritas dari istri kelompok nelayan adalah ibu rumah tangga yang tidak memiliki penghasilan dan memiliki banyak waktu kosong yang dapat di efisiensikan untuk menambah pendapatan. Saat ini pengelolaan limbah ikan dari pengolahan ikan asin atau tawar hanya di buang dan di timbun sehingga menimbulkan bau kurang sedap dan dapat mengganggu kesehatan masyarakat sekitar, serta produksi ikan asin atau tawar menjadi kurang higienis. Salah satu upaya untuk mengurangi limbah dari pengolahan ikan yaitu dengan memanfaatkan limbah hasil samping pengolahan ikan berupa kepala ikan dan isi perut ikan menjadi pakan ayam boiler. Hal ini karena tingginya kandungan protein pada limbah tersebut sehingga dapat dimanfaatkan sebagai sumber nutrisi bagi ayam boiler. Pemanfaatan limbah menjadi pakan buatan dinilai sebagai salah satu solusi untuk menekan biaya produksi dan meningkatkan nilai ekonomi dari limbah (Alex, 2011). Limbah ikan mengandung protein, mineral dan vitamin B. Protein ikan terdiri dari asam amino yang tidak terdapat pada tumbuhan. Kandungan gizi yang tinggi pada limbah ikan dapat meningkatkan produksi dan nilai gizi pada telur, dan daging ayam ternak. Pakan ayam yang berkualitas tidak hanya bisa dilihat dari jumlahnya, tetapi juga dari nilai gizinya antara lain protein, lemak, dan mineral (Fitasari dkk., 2016). Saat ini, masyarakat dunia sedang menghadapi pandemi COVID-19 yang 
memaksa kita untuk mengurangi aktivitas di luar rumah. Pelaksanaan pelatihan PKM di masa pandemi dilakukan secara daring untuk mengurangi potensi penyebaran COVID-19 melalui pengurangan interaksi fisik dengan masyarakat.

Perkembangan teknologi informasi dan komunikasi di era Industri 4.0 telah memiliki pengaruh yang besar terhadap proses pengajaran dan pembelajaran. Kemudahan akses teknologi telah digunakan oleh para pengajar untuk meningkatkan kualitas pendidikan. Seperti yang telah disampaikan oleh Keengwe dan Georgina (2012) dalam penelitiannya telah menyatakan bahwa perkembangan teknologi memberikan perubahan terhadap pelaksanaan pengajaran dan pembelajaran. Beberapa penelitian telah menunjukkan bahwa teknologi memberikan banyak pengaruh positif terhadap pembelajaran bahasa seperti membaca menggunakan video (Gheytasi dkk., 2015). Internet telah dipadukan sebagai alat untuk melengkapi aktivitas pembelajaran bahasa (Handarini dkk., 2020; Martins, 2015). Salah satu media teknologi yang sering digunakan saat ini adalah aplikasi di telepon genggam. Hasil penelitian menunjukan bahwa siswa yang banyak berinteraksi dengan aplikasi di telepon genggam dapat lebih mudah memahami isi teks bacaan (Gheytasi dkk., 2015).

Limbah ikan yang merupakan hasil akhir dari pengolahan ikan dapat berdampak buruk bagi kesehatan masyarakat dan berpotensi merusak lingkungan sekitar bila terus di biarkan tanpa ada penanganan yang serius untuk mengatasi limbah tersebut. Belum adanya pembelajaran tentang pemanfaatan limbah ikan menjadi pakan ternak kepada kelompok nelayan Belawan Sumatera Utara, baik berupa video tutorial maupun buku pedoman.

Tujuan dari pengabdian masyarakat ini adalah untuk melatih kelompok nelayan dalam memanfaatkan limbah ikan menjadi pakan ternak. Tujuan dari pengabdian ini adalah untuk mengurangi limbah yang tidak termanfaatkan dan memberi edukasi kepada kelompok nelayan secara daring.

\section{METODE}

Seluruh rangkaian kegiatan Pengabdian kepada Masyarakat ini dilakukan secara daring dengan memanfaatkan media Zoom Meeting Online. Kegiatan ini terdiri atas beberapa tahapan yang digambarkan pada gambar 1 . 


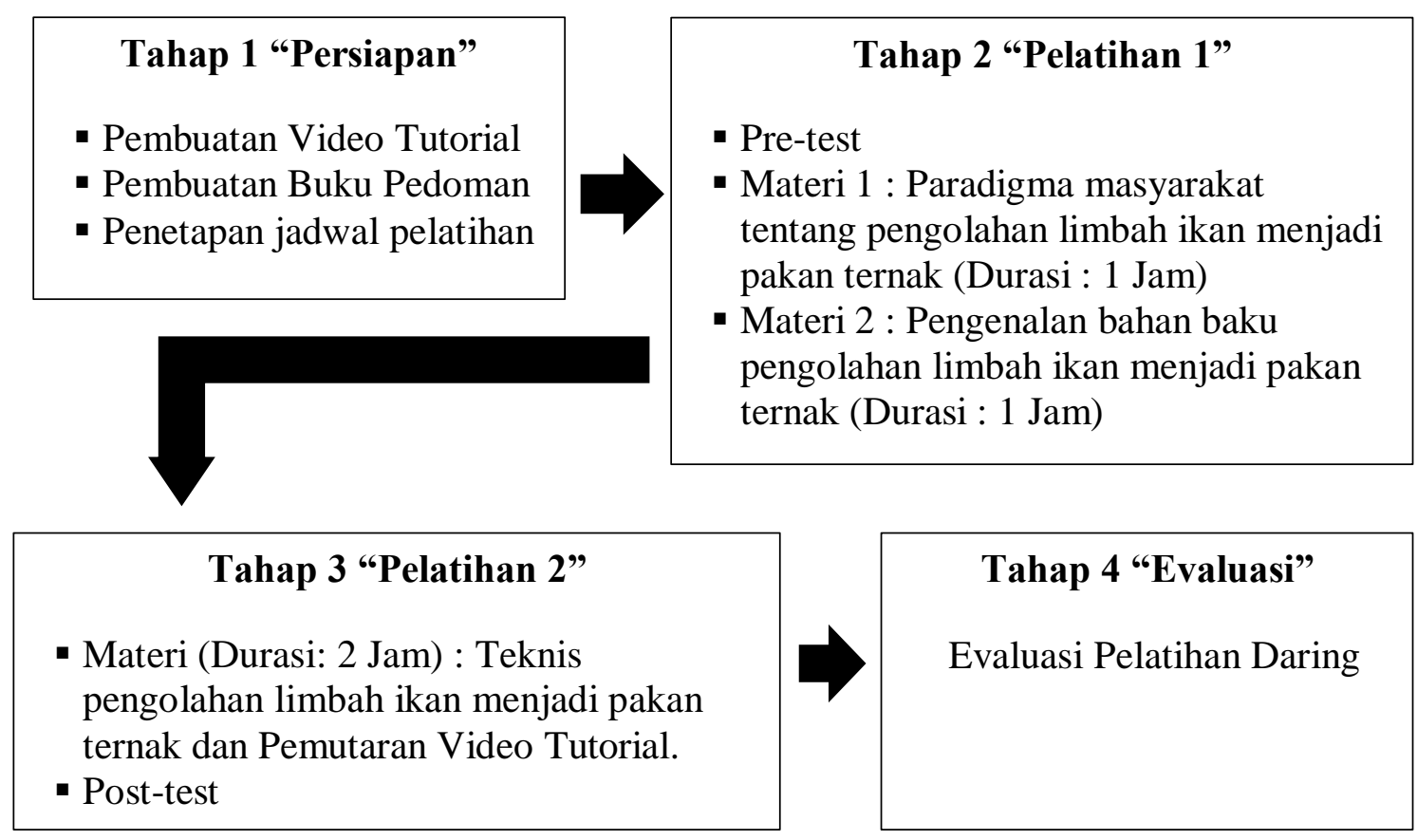

Gambar 1. Tahapan pelaksanaan Kegiatan Pengabdian kepada Masyarakat secara Daring

Secara umum, kegiatan ini terdiri atas empat tahap. Pada tahap 1, dilakukan persiapan yakni dengan pembuatan video tutorial pengolahan limbah ikan yang dibuat sangat detail agar setiap individu masyarakat dapat memahami prosesnya. Selain video, dibuat juga buku pedoman pelaksanaan yang berjudul "Pembuatan Pakan Ternak Berbahan Dasar Limbah Ikan” buku ini di buat betujuan agar masyarakat dapat memahami dari bahaya dari limbah ikan dan proses pengolahan limbah ikan menjadi pellet.

Pada tahap ke-2 dan ke-3 dilakukan pelatihan secara daring dengan menyampaikan materi-materi melalui power point yang berisi substansi yang terdapat pada buku pedoman dan penyampaiakan video tutorial. Pada tahap ke-4 dilakukan evaluasi menggunakan zoom meeting online bersama masyarakat guna untuk memantau jumlah masyarakat yang sudah melaksanakan kegiatan tersebut secara mandiri.

\section{HASIL, PEMBAHASAN, DAN DAMPAK}

Pelatihan ini bertujuan untuk meningkatkan keterampilan kelompok nelayan dalam memanfaatkan dan mengolah limbah ikan menjadi pakan ternak. Dengan keterampilan ini kelompok nelayan dapat mengurangi dampak kerusakan lingkungan dan kesehatan dari limbah ikan dan dapat meningkatkan perekonomian kelompok nelayan dari produksi pakan ternak berbahan dasar limbah ikan. 


\section{Pelaksanaan Pelatihan Secara Daring}

Program ini dilaksanakan mengikuti Adendum Program Kreativitas Mahasiswa Tahun 2020 yang terbitkan oleh Kementerian Pendidikan dan Kebudayaan, dimana seluruh pelaksanaan PKM M hanya dapat dilaksanakan secara daring (tanpa mengunjungi masyarakat secara langsung). Kegiatan ini berlangsung selama 6 (enam) minggu dimulai dari tahap 1 hingga tahap 4 (Gambar 1). Pada tahap 1, tim PKM M UMA telah membuat 1 buah video tutorial dengan durasi 5 Menit 51 Detik yang akan ditampilkan pada saat pelatihan menggunakan Zoom Meeting Online (Gambar 2). Selain itu, Tim PKM M UMA juga telah membuat buku pedoman pelaksanaan program yang terdiri atas 14 halaman (Gambar 3a). Untuk meningkatkan efisiensi pelaksanaan pelatihan, produk pengabdian berupa video dan buku pedoman dibagikan kepada masyarakat dalam bentuk soft copy yang dikirimkan melalui Whatsapp, Youtube, dan CD bagi peserta yang tidak memiliki akses Internet serta hard copy buku pedoman yang dikirimkan kepada perwakilan masyarakat melalui ekspedisi Gojek (Gambar 3b).

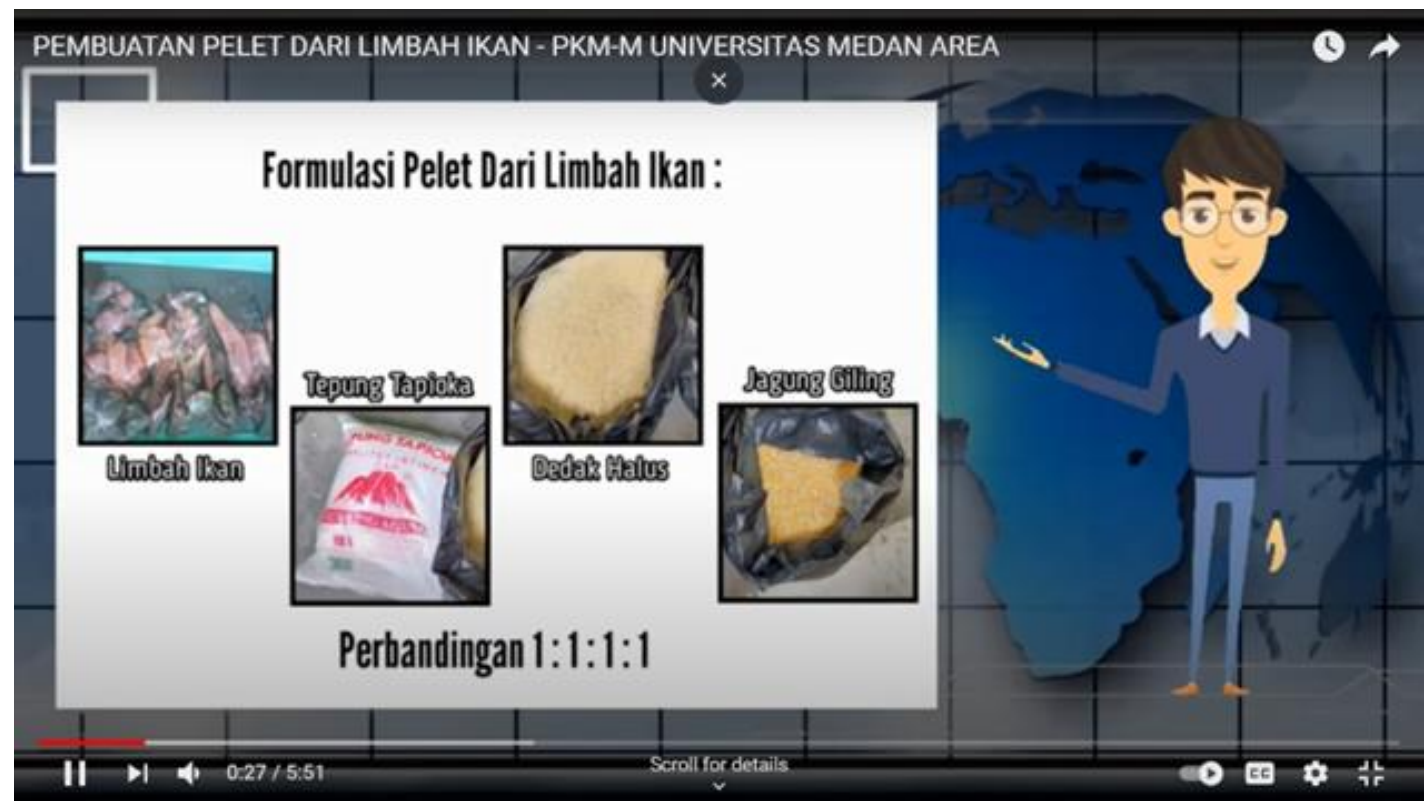

Gambar 2. Video Tutorial Pembuatan Pelet dari Limbah Ikan 

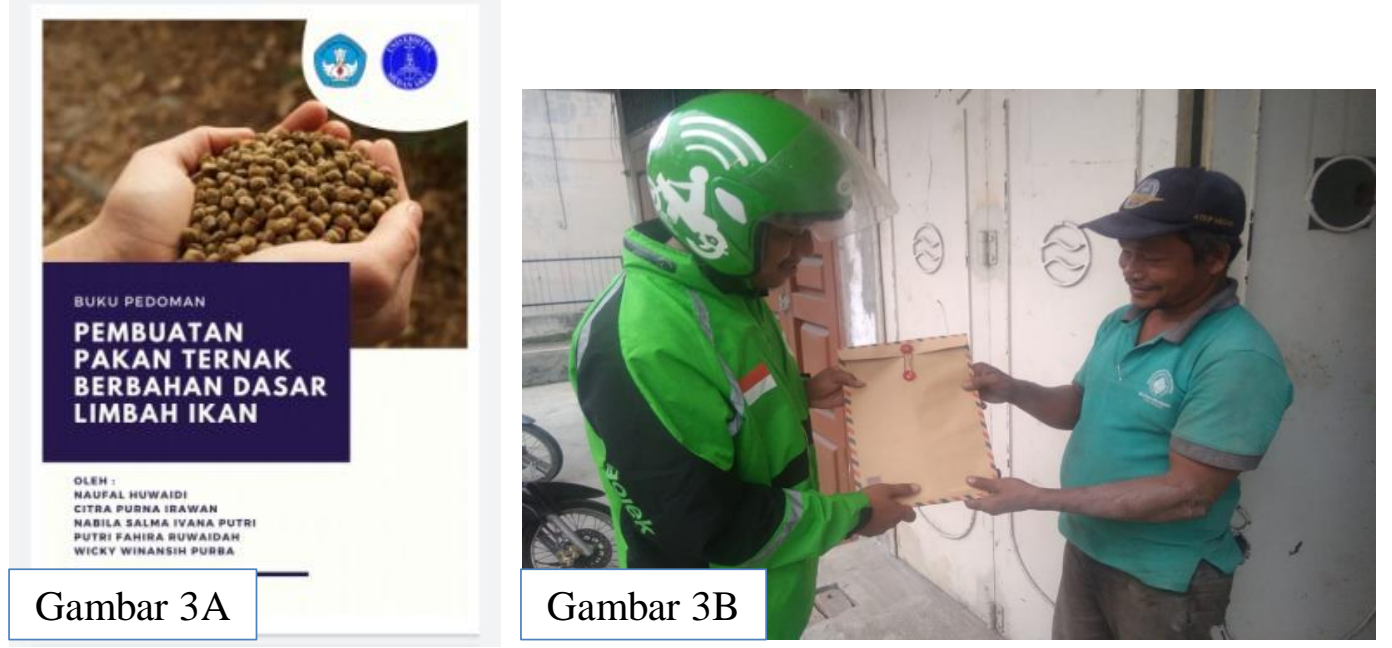

Gambar 3A. Buku pedoman pelaksanaan program; Gambar 3B. Penyerahan CD dan Hardcopy Buku Pedoman kepada perwakilan masyarakat

\section{Pelatihan 1}

Pelatihan 1 dilakukan untuk memberikan informasi dan pengetahuan baru kepada masyarakat mitra dalam pengolahan limbah ikan menjadi pakan ternak. Kegiatan ini diawali dengan pre-test tentang pengetahuan masyarakat mitra mengenai pengolahan limbah ikan. Pelatihan 1 ini diikuti oleh 15 orang yang terdiri atas ibu rumah tangga, pemuda desa yang telah mengalami PHK akibat pandemi, dan nelayan. Setelah dilakukan pre-test, kegiatan selanjutnya yaitu pemberian materi yang terdiri atas 2 sesi. Pada sesi 1 dengan durasi 1 jam berisi materi tentang informasi dan perubahan paradigma masyarakat mengenai kesehatan lingkungan, pentingnya pengelolaan dan pengolahan limbah, serta peluang pengolahan limbah ikan menjadi suatu produk yang memiliki nilai ekonomi (Gambar 4).

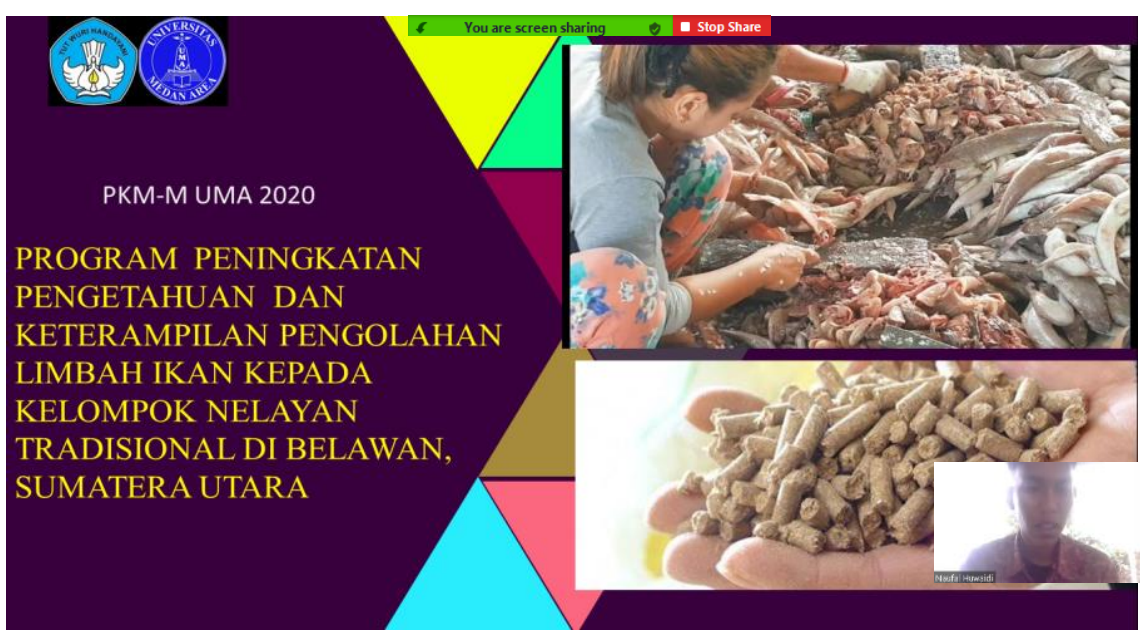

Gambar 4. Pelaksanaan Pelatihan 1 Secara Daring 
Pada sesi 2, disampaikan materi pengenalan bahan baku pengolahan limbah ikan menjadi pakan ternak oleh Tim PKM M UMA kepada mitra. Mitra sangat antusias mengikuti kegiatan ini yang dibuktikan dengan sesi tanya jawab yang semula hanya dialokasikan 15 menit, menjadi hampir 40 menit. Penyampaian materi ke-2 kepada mitra merupakan langkah awal untuk memasuki materi yang akan disampaikan pada pertemuan Pelatihan ke-2. Pada sesi ini, masyarakat diberi penekanan bahwa mengolah limbah ikan menjadi pakan ternak sangat mudah dan sangat mungin dikerjakan oleh masyarakat secara mandiri. Dokumentasi sebagian peserta disajikan pada Gambar 5.

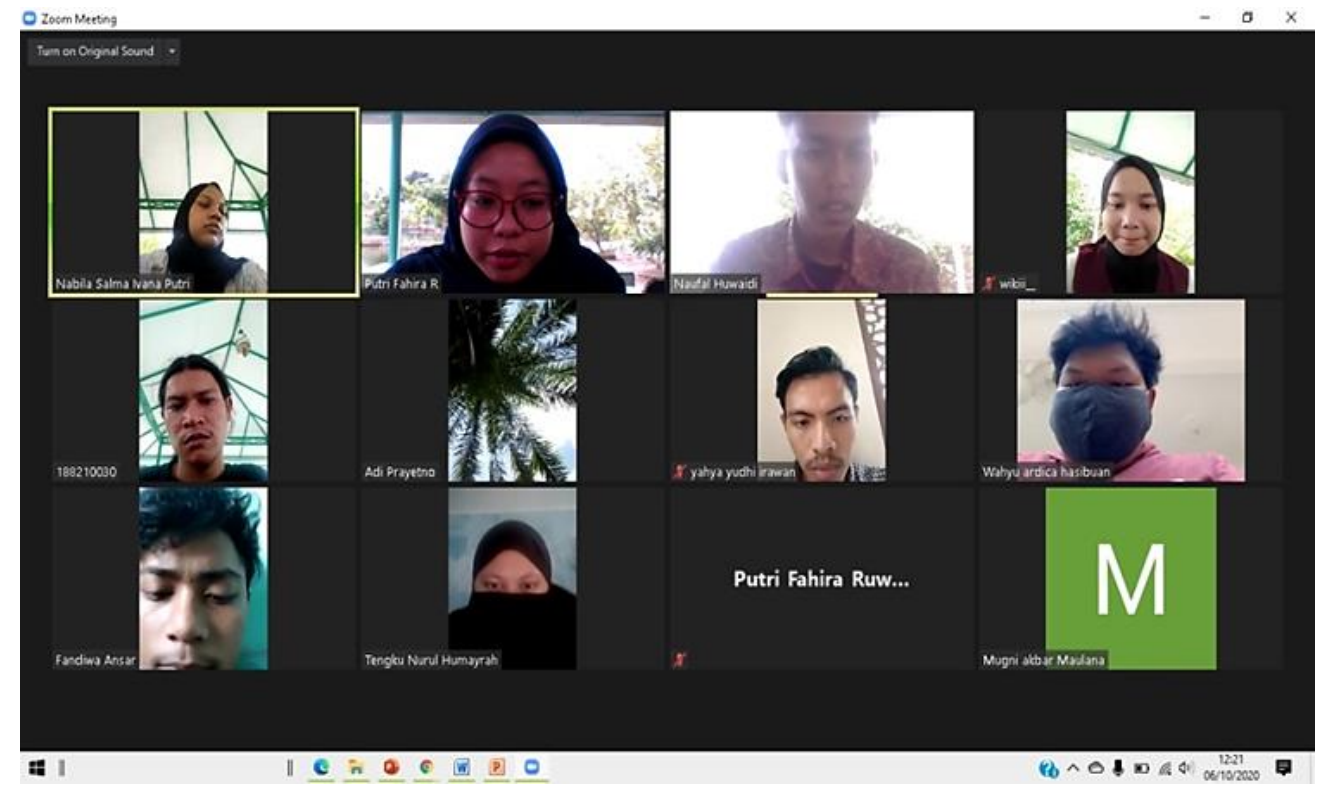

Gambar 5. Dokumentasi Pelaksanaan Pelatihan 1

\section{Pelatihan 2}

Pelatihan 2 dilakukan untuk memberikan pemahaman yang lebih mendalam tentang teknis pengolahan limbah ikan menjadi pakan ternak yang disampaikan dalam bentuk video tutorial Gambar 6. Selain pemutaran video, masyarakat juga telah dikirimkan Buku Pedoman Pelaksanaan melalui ekspedisi Gojek (Gambar 3b). Pengolahan limbah ikan menjadi pakan ternak ayam dilakukan dengan tahapan sebagai berikut:

1. Cuci limbah ikan yang akan diolah hingga bersih, hingga tidak ada darah yang menempel pada ingsang 197anic197i perut ikan, lalu tiriskan.

2. Siapkan kompor dan panci yang sudah berisi air, lalu rebus dengan menggunakan api sedang selama \pm 25 menit.

3. Setelah \pm 25 menit, matikan kompor dan biarkan sejenak agar bahan menjadi dingin. 
4. Tiriskan bahan menggunakan saringan agar air rebusan terbuang, lalu haluskan menggunakan blender.

5. Campurkan bahan dengan bahan lain yakni jagung, dedak, tepung sesuai komposisi, kemudian aduk rata (Gambar 7).

6. Bentuk adonan menggunakan mesin penggiling pelet, lalu keringkan, dan pakan siap dikemas.

Pada pelatihan kedua, masyarakat mitra menerima materi pembuatan pelet dengan sangat detil yang disampaikan oleh Tim PKM M UMA agar dapat diterima dan diaplikasikan langsung oleh masyarakat di rumah amsing-masing secara mandiri. Pada sesi ini juga dilaksanakan post-test kepada masyarakat mitra terhadap pelatihan yang telah dilaksanakan selama 2 kali dengan 3 sesi materi.

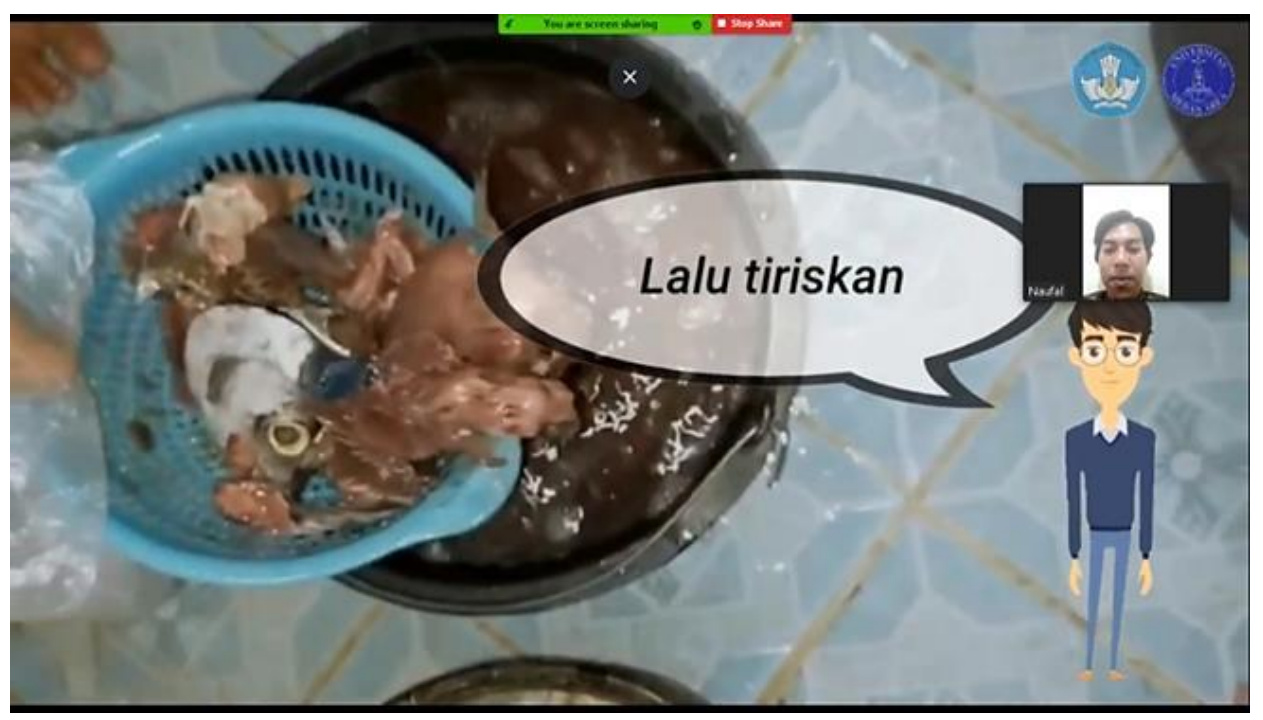

Gambar 6. Penyampaian teknik pengolahan limbah ikan menggunakan video tutorial

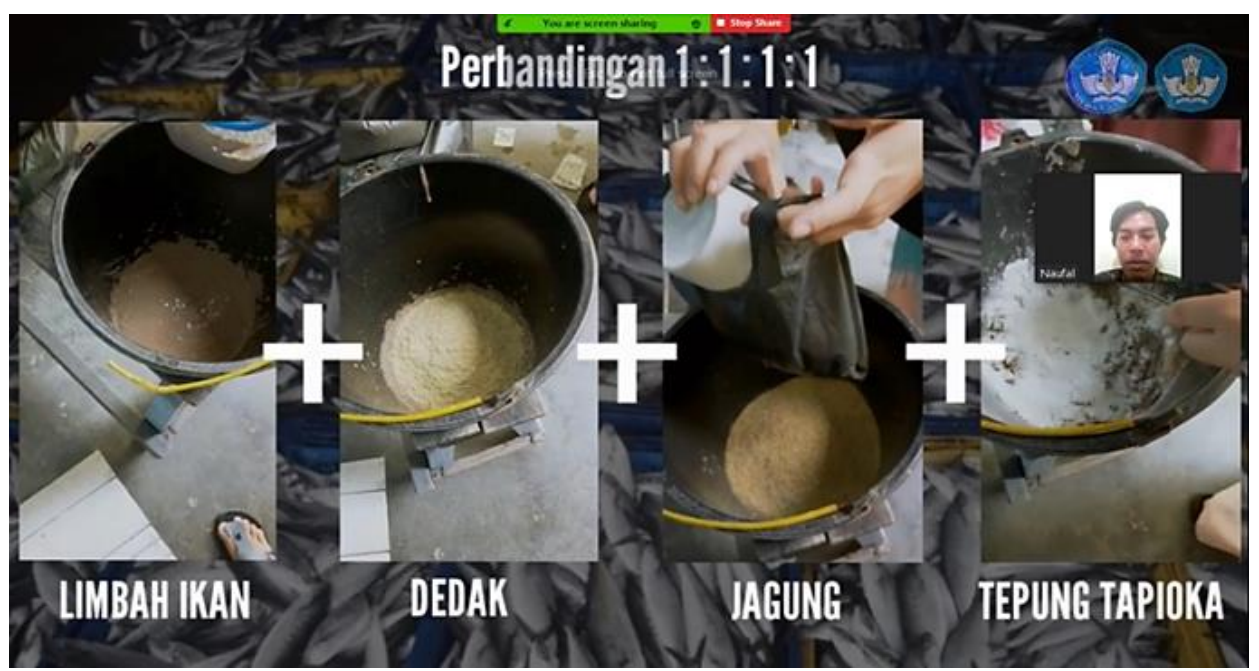

Gambar 7. Penyampaian komposisi bahan menggunakan video tutorial 


\section{Evaluasi Pelaksanaan Pelatihan Daring}

Evaluasi pelaksanaan program ini dilakukan dengan membagikan kuisioner yang diisi secara online oleh mitra menggunakan media google formulir. Evaluasi dilakukan dengan membandingkan pre-test dan post-test kepada 15 orang peserta serta wawancara kepada perwakilan mitra secara daring untuk memberikan komentar, saran, dan harapan setelah dilaksanakan program ini. Hasil evaluasi pelaksanaan disajikan pada Gambar 8.

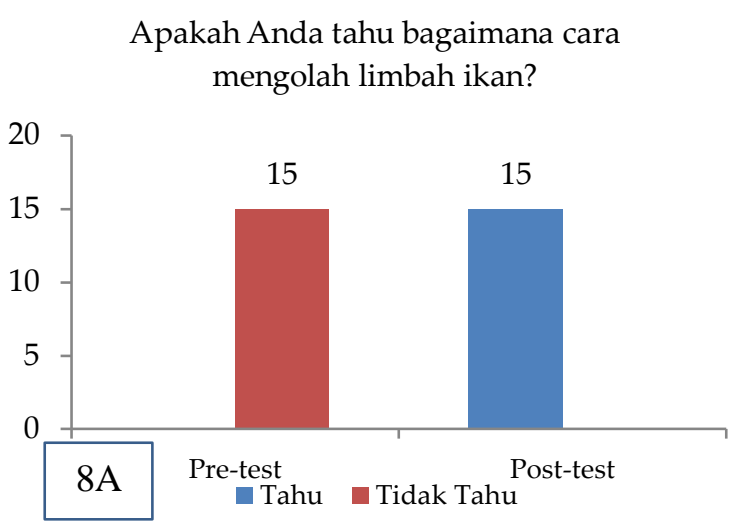

Apakah Anda tahu komposisi bahan pembuatan pakan ternak?

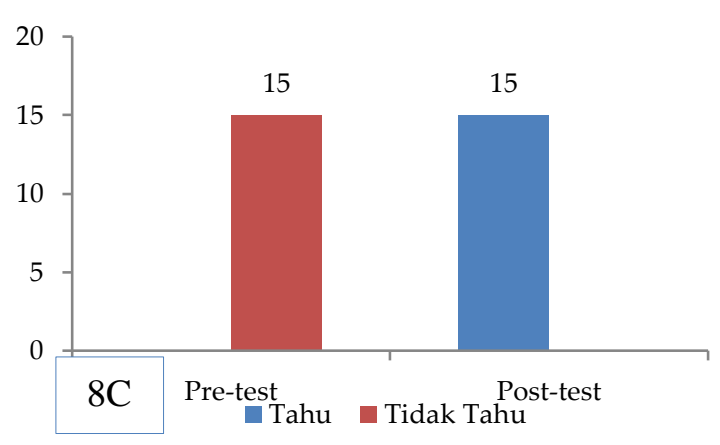

Apakah Anda tahu bahwa limbah ikan dapat diolah menjadi pelet untuk pakan

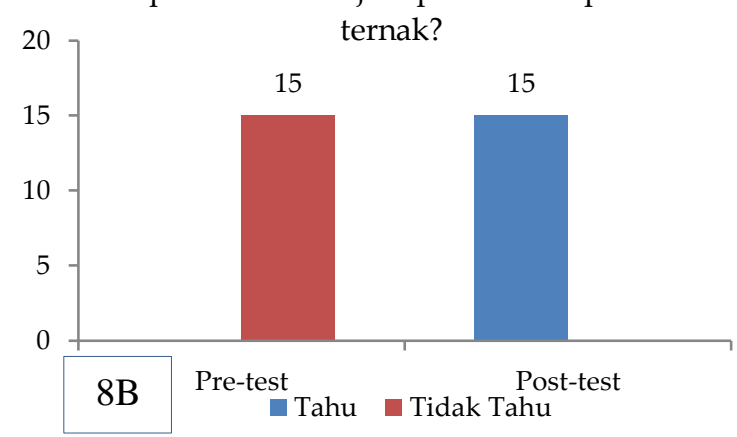

Apakah Anda berminat untuk mengolah limbah ikan menjadi pelet pakan ternak?

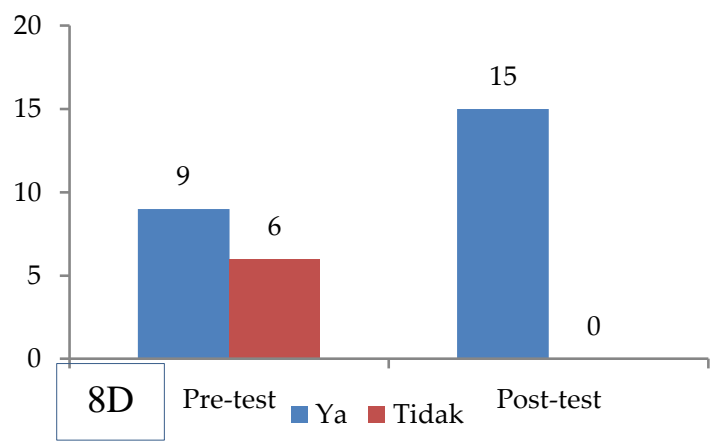

Gambar 8. Hasil Pre-test dan Post-test

Hasil pre-test dan post-test pelaksanaan program yang disajikan pada Gambar 8 menunjukkan bahwa sebelum adanya program ini mitra tidak tau bagaimana cara mengolah limbah ikan, selama ini mitra hanya membuang limbah ikan begitu saja sehingga seringkali menimbulkan bau busuk (Gambar 8A). Program ini dapat meningkatkan pengetahuan mitra bahwa limbah ikan dapat diolah menjadi pelet untuk pakan ternak (Gambar 8B) dan memberikan informasi kepada masyarakat tentang komposisi bahan pembuatan pakan ternak berbahan dasar limbah ikan (Gambar 8C). Selain itu, melalui program ini juga meningkatkan minat mitra untuk mengolah limbah 
ikan menjadi pelet pakan ternak yang jika dilaksanakan secara berkelanjutan dapat menjadi suatu unit usaha baru dan meningkatkan pendapatan masyarakat (Gambar 8D).

Pada sesi evaluasi, perwakilan masyarakat juga menyampaikan bahwa program ini sangat bermanfaat bagi mitra terutama sebagai alternatif penghasilan baru bagi pemudapemuda desa yang telah mengalami PHK akibat pandemi maupun bagi ibu rumah tangga untuk mendapatkan penghasilan tambahan. Pelaksanaan pelatihan secara daring ini, terdapat berbagai kendala yakni sinyal Internet yang cukup lambat sehingga Tim PKM M UMA membuat alternatif tambahan yaitu dengan mengirimkan CD dan buku pedoman terlebih dahulu sebelum dilaksanakan pelatihan. Selain itu, proses pendampingan kepada masyarakat juga dilakukan melalui komunikasi selular (telfon) maupun chat menggunakan whatsapp. Kendala lain yang dihadapi yaitu tidak semua mitra melek teknologi informasi terutama aplikasi Zoom Meeting Online sehingga Tim PKM M UMA bekerja sama dengan anak dari mitra sasaran yang berada di lokasi program untuk membantu pelaksanaan teknis pelatihan online menggunakan media Zoom Meeting Online. Masyarakat berharap COVID-19 segera berlalu sehingga pelaksanaan pelatihan ini dapat ditindaklanjuti secara langsung (luring).

\section{SIMPULAN}

Pelaksanaan program ini sangat bermanfaat bagi mitra sasaran untuk meningkatkan pengetahuan dan keterampilan dalam mengolah limbah ikan yang setiap hari dihasilkan menjadi suatu pakan ternak. Pengolahan limbah ikan menjadi pakan ternak dapat menjadi alternatif unit usaha baru yang dapat meningkatkan penghasilan terutama bagi pemuda yang terkena PHK akibat pandemi dan bagi ibu rumah tangga yang ingin mendapatkan pemasukkan tambahan. Secara umum, pelaksanaan program secara daring berjalan dengan baik hanya saja perlu ada tindak lanjut secara luring untuk lebih memastikan bahwa program ini dilaksanakan oleh masyarakat secara berkelanjutan.

\section{UCAPAN TERIMAKASIH}

Ucapan terima kasih disampaikan kepada Kementerian Pendidikan dan Kebudayaan yang telah memberikan hibah melalui skema Program Kreativitas Mahasiswa Bidang Pengabdian Kepada Masyarakat (PKM M) Tahun 2020. Selain itu, Tim PKM M UMA juga menyampaikan terima kasih kepada masyarakat Belawan khususnya Desa atau Jalan Pulau Seram atas kerjasama dan partisipasinya dalam kegiatan ini. 


\section{DAFTAR PUSTAKA}

Alex, S. M. 2011 Untung Besar Budidaya Aneka Jamur. Yogyakarta: Pustaka Baru Press

Fitasari, E., Reo, K., \& Niswi, N. Penggunaan kadar protein berbeda pada ayam kampung terhadap penampilan produksi dan kecernaan protein. Jurnal Ilmu-Ilmu Peternakan, 26 (2) : 73-83. http://dx.doi.org/10.21776/ub.jiip.2016.026.02.10

Gheytasi, M., Azizifar, A., \& Gowhary, H. (2015). The Effect of Smartphone on the Reading Comprehension Proficiency of Iranian EFL Learners. Procedia - Social and Behavioral Sciences, $199, \quad 225-230$. https://doi.org/10.1016/J.SBSPRO.2015.07.510

Handarini, Oktafia Ika, dan Siti Sri Wulandari (2020). "Pembelajaran Daring Sebagai Upaya Study From Home (SFH) Selama Pandemi Covid 19." Jurnal Pendidikan Administrasi Perkantoran (JPAP). $\quad 8, \quad$ no. $\quad 3.498$. https://journal.unesa.ac.id/index.php/jpap/article/view/8503.

Keengwe, J., \& Georgina, D. (2012). The digital course training workshop for online learning and teaching. Education and Information Technologies, 17(4), 365-379. https://doi.org/10.1007/s10639-011-9164-x

Martins, M. de L. (2015). How to Effectively Integrate Technology in the Foreign Language Classroom for Learning and Collaboration. Procedia - Social and Behavioral Sciences, 174, 77-84. https://doi.org/10.1016/J.SBSPRO.2015.01.629

Siahaan, F. T. S., Mudzakir, A. K., \& Dewi, D. A. N. (2016). Tingkat Pemanfaatan Fasilitas Dasar dan Fungsional di Pelabuhan Perikanan Samudera Belawan dalam Menunjang Kegiatan Penangkapan Ikan. Journal of Fisheries Resources Utilization Management and Technology, 5(2), 55-63. Retrieved from https://ejournal3.undip.ac.id/index.php/jfrumt/article/view/11827 